\title{
Enhancing learning outcomes from industry engagement in Australian engineering education
}

\author{
Sally A. Male ${ }^{1}$ and Robin King ${ }^{2}$ \\ sally.male@uwa.edu.au; robin.king@uts.edu.au \\ Corresponding author: Sally Male \\ ${ }^{1}$ School of Engineering, The University of Western Australia, Perth, Western Australia \\ ${ }^{b}$ Faculty of Engineering and IT, University of Technology, Sydney; Australian Council of Engineering \\ Deans
}

\begin{abstract}
Industry engagement, commonly implemented as a 12 week industry placement during a vacation towards the end of the degree, has traditionally been a provider-mandated component of externally accredited professional engineering degrees in Australia. Such placements are intended to bridge knowledge and capability gaps between academic study and engineering employment and contextualise the final phase of academic study. Changes in the composition of Australia's engineering industries have made it progressively harder to source such placements. In-curriculum exposure to engineering practice has also been expected, but has been delivered with considerable variability. In 2014 the authors completed a national project, led by the Australian Council of Engineering Deans (ACED), with peak industry bodies and several partner universities, funded from the Commonwealth Department of Industry Workplace Innovation Program, to explore how improving industry engagement could contribute further to engineering graduates' learning outcomes and employability. The data collected from the engineering students and employers, reported in this paper, can now be regarded as baseline data on industry engagement, against which subsequent developments can be referenced. For the first time, students' ratings of the value of different methods for industry engagement are shown to be related to their 'authenticity'. Several industry-inspired in-curriculum interventions were also trialled at partner universities. Guidelines for good practice were developed from melding the experiential findings with theoretical perspectives. In the years since completing the project, the accreditation body, Engineers Australia, has updated and intensified its focus on engagement with practice (including changing its language from 'exposure' to 'engagement'), and many engineering faculties have significantly enhanced their models and requirements for work integrated learning and industry engagement. This paper outlines these changes and examples of new implementations, including virtual and electronically-mediated methods that also reflect ongoing changes in engineering industry practice.
\end{abstract}

Keywords: engineering education, work integrated learning, curriculum development, co-op programs, accreditation, internships, work-based learning, employability

\section{Background and context}

As for many professional areas, the pathway to independent practice in engineering is a combination of a formative qualification and supervised experience. Since 1980, the formative qualification for professional engineering in Australia has been a four-year bachelor honours degree, now at Level 8 of the Australian Qualifications Framework (AQF), or an 'entry to practice' master's degree at AQF Level 9. These qualifications are offered by 35 public 
universities and a very small number of private providers, and are externally accredited by the Australian professional organisation, Engineers Australia (EA). The engineering profession globally has adopted this qualification plus experience model and has formalised standards through international 'educational accords' and 'professional competence agreements' (International Engineering Alliance, 2014), of which EA is a foundation member.

To maintain its currency and value, engineering education in Australia has periodically reviewed itself, in collaboration with its stakeholders, including EA. The most recent national review (King, 2008) recommended focus on improving the 'authenticity' of engineering education in terms of best practice curriculum (i.e. emphasis on student-centred, active learning, and alignment of outcomes, pedagogy, and assessment); good quality exposure to engineering practice; and effective delivery by authentic educators who are knowledgeable of educational best-practice and contemporary engineering practice, as well as research in engineering science.

Engineering graduates, together with those in science, technology, and mathematics, tend to perform well in employers' assessments of business-critical skills, including active learning, critical thinking, and complex and creative problem solving (Prinsley \& Baranyai, 2015). Nevertheless, employers of engineers continue to report gaps between graduates' capabilities and employers' expectations, particularly in interpersonal communication and other workplace knowledge and skills.

An EA accredited program must deliver graduates with competency in sixteen generic areas of knowledge and basic skills, engineering application ability, and personal and professional attributes (Engineers Australia, 2013). A key criterion for EA program accreditation is 'exposure to engineering practice', intended to ensure that academic knowledge and skills are reinforced and contextualised and to prepare graduates for employment. The current EA guideline (Bradley, 2008, p. 18) specifies 13 ways of providing exposure to practice, as listed in Table 1. Of these, exposure to ethics is mandated, and 'at least 12 weeks of practical experience in an engineering environment outside the teaching establishment' is strongly recommended. Others come under the broad category of 'work integrated learning' (WIL).

Table 1: Engineers Australia's Listed Methodologies and Activities for Students' Exposure to Engineering Practice

\begin{tabular}{|c|c|}
\hline $\begin{array}{l}\text { Practical experience in an engineering } \\
\text { environment outside the teaching } \\
\text { establishment }\end{array}$ & $\begin{array}{l}\text { Study of industry policies, processes, } \\
\text { practices and benchmarks }\end{array}$ \\
\hline $\begin{array}{l}\text { Mandatory exposure to lectures on } \\
\text { professional ethics and conduct }\end{array}$ & $\begin{array}{l}\text { Direct industry input of data and } \\
\text { advice to problem solving, projects } \\
\text { and evaluation tasks }\end{array}$ \\
\hline Use of guest presenters & $\begin{array}{l}\text { Industry based investigatory } \\
\text { assignments }\end{array}$ \\
\hline Use of staff with industry experience & Industry research for feasibility studies \\
\hline Interviewing engineering professionals & $\begin{array}{l}\text { Electronic links with practising } \\
\text { professionals }\end{array}$ \\
\hline Industry visits and inspections & Case studies \\
\hline Industry based final year projects & \\
\hline
\end{tabular}

Following the EA guideline, for many decades almost all universities have mandated engineering students to complete and report satisfactorily on at least 12 weeks of engineeringrelated work, in order to qualify to graduate. In almost all instances these placements have not been awarded academic credit, and have traditionally been paid. Ideally, this industry 
placement would be taken during the vacation before their final year of study and typically would not be tightly structured or overseen by the faculty. Making the student largely responsible for acquiring their placement is seen to be part of their capabilities development. A small number of universities also offer industry internships of six months duration within their programs, similar to those that are often expected by employers of engineering graduates in France and Germany.

In 2017, the Australian higher education system graduated approximately 8,000 domestic (15\% women) and 4,300 international (20\% women) students from accredited bachelor (honours) and 'entry to practice' master degree programs in engineering (Australian Government Department of Education \& Training, 2018). Facilitating good quality in-industry experience to the increasing number of students presents an increasing challenge.

In Australia, privatisation of formerly state-owned engineering infrastructure, movement offshore of engineering-based manufacturing, and the rise of contract-based engineering services firms have contributed to a decline in the availability of traditional work experience placements, particularly for international students. It is not uncommon, but is obviously unsatisfactory, for students who have met the academic requirements to graduate, to have to delay their graduation until they have completed the required period of industry experience. Simultaneously, the increasing demand for experienced engineers is not satisfied by the flowthrough of new domestic graduates, and experienced engineers make up a significant proportion of inward skilled migration.

Whilst the industry placement has continued as the main method for student exposure to practice, most faculties have also included several of the other listed WIL methodologies and activities. The capacity to design and implement strongly practice-based curricula is, however, limited by the decline in the numbers of academics with recent industry experience, other than in research laboratories. A survey of approximately one-third of Australian engineering educators found that few engineering academics had more than four years of industry experience, and that such experience was gained, on average, more than fifteen years previously to the survey (Cameron, Reidsema, \& Hadgraft, 2011).

In 2012, the combination of increasing demand for engineers, especially for the resources sector, industry concerns about engineering graduates' employability skills, and governments' concerns about attrition of students from engineering, led to the Australian Council of Engineering Deans (ACED) being commissioned by the Australian Government's Department of Industry Workplace Innovation Program to examine the issue of industry engagement of engineering students. The study, completed in 2014 and reported in this paper, reconsidered the use of unstructured industry placements and industry-informed classroom learning and activities, to provide engineering students with improved exposure to practice. Since 2014, ACED and its members have been revisiting how best to implement industry engagement in their engineering degrees, and EA has revised its guideline on the corresponding accreditation criterion. These developments are described later in the paper.

With employers of graduates from all fields of education and their peak bodies expressing concerns about graduates' skills for employability, in 2015 the higher education and business peak bodies announced a National WIL Strategy (Universities Australia, Australian Chamber of Commerce and Industry, Ai Group, Business Council of Australia, \& Australian Collaborative Education Network, 2015) for all undergraduate degrees. WIL activity has increased in many fields. The national quality assurance agency has subsequently produced a Guidance Note (Australian Government Tertiary Education Quality and Standards Agency, 2017) that incorporated experience from the ACED community. It is to encourage continuous improvement in the implementation of WIL in all fields that we offer the experience of engineering, as discussed in this paper. 


\section{Exposure to practice in engineering education: The 2012-14 research study}

Two overarching research questions that framed the 2012-14 national project were:

1. What is the current student experience of engineering practice?

2. What (evidence-based) methods can be used to improve this experience?

With human research ethics approval, we used surveys, interviews, and focus groups to explore students' and industry perceptions of the benefits and challenges of workplace and classroom methods for learning about practice. The project grant also provided seed funding to trial and evaluate a small number of initiatives that brought aspects of contemporary industry practice into engineering classes. The project phases and descriptive results are summarised in previous conference papers (Male \& King, 2014b; Male, King, \& Hargreaves, 2016), and recommendations based on the project are available in guidelines (Male \& King, 2014a). In this paper, we first outline our model of engineering education into which exposure to practice fits. The data collection and key findings for each phase are then reported, including new analysis of student perception data that reveals a positive relationship between students' ratings of the methods used for industry exposure and their authenticity.

\section{Theoretical framework and model}

Underpinning the research questions is a notion of an 'ideal' student experience and transition into engineering employment. The engineering curriculum is the education providers' expression of the intended student experience, but we recognise that there are inevitably differences between the 'intended', 'enacted' and 'experienced' curriculum (Billett, 2011, pp.16-24). The intended engineering curriculum would invariably include good quality (authentic) exposure to practice; how this is experienced is discussed in the paper. Well designed and experienced exposure to practice throughout the curriculum would contribute to addressing three issues raised by employers: perceived gaps between the capabilities of engineering graduates and those required for engineering practice; attrition of graduates from the profession; and attrition from study during the engineering degree. We comment briefly on each of these points.

Graduate capability gaps exhibited by engineers reported by employers in the UK, USA, and Australia are most often identified to be in areas of communications and teamwork or social skills (Bodmer, Leu, Mira, \& Rutter, 2002; Nair, Patil, \& Mertova, 2009). In Australia, (King, 2008) reported improved oral communication and teamwork, but deficiencies in written communication. Skills gaps in practical application of theory and business skills (King, 2008; Male, Bush, \& Chapman, 2010; Spinks, Silburn, \& Birchall, 2006) have also been identified.

These gaps reflect the dominant focus on engineering science and analytical techniques in engineering degrees, from the latter half of the $20^{\text {th }}$ Century, and educators' lack of understanding of engineering practice (Trevelyan, 2010) as a socio-technical profession requiring capabilities that are both technical and social in nature (Leydens, 2012). Investigating the learning of experienced engineers in the workplace, Rooney et al. (2012) found that they learned through situated, relational, collective practices engaging with team members who are in diverse roles. In formulating four principles for the redesign of engineering education, Sheppard, Macatangay, Colby, and Sullivan (2009) have recommended that engineering practice should be central to engineering education, with their third principle being: integrate identity, knowledge, and skills through approximations to practice (p. 200). Our ideal model for good engineering education places socio-technical practice at its core, as described below.

The apparent attrition of engineering graduates from the profession is high. Trevelyan and Tilli (2010, p. 101) reported that approximately 40 per cent of engineering graduates in Australia at the time of the 2006 census were not working in engineering-related roles. A similar figure can be deduced from the 2011 census data, if those not working are excluded (Palmer, Tolson, Young, \& Campbell, 2015). The majority of the 'others' are in 'general management' roles. 
Many of the latter are likely to be in engineering companies and others may be in the finance and services sectors, as engineering degrees provide good routes into quantitative, problem solving and management occupations. Nevertheless, one possible cause of graduate engineers leaving engineering is a mismatch between graduates' expectations of predominantly technical functions - as conveyed by the curriculum and its teachers - and their experiences of engineering practice. Faulkner (2007) discusses identity conflict experienced by engineers who felt that social aspects of their work were not 'real engineering'.

Student attrition and graduate completion data indicate that at least 65 per cent of Australian students commencing a four-year bachelor's degree in engineering are likely to graduate, some at another institution (Australian Council of Engineering Deans, 2017; Godfrey \& King, 2011). Most of the attrition occurs during or after the first or second year of study. Amongst the reasons cited by students for early-year attrition is 'lack of relevance' of the curriculum to their perception of their future. Countering this, early identity formation has been found to be valuable in a French engineering program based on an apprenticeship model (Blandin, 2012). A second reason for attrition is failure to master difficult concepts in key engineering subjects.

Threshold concepts are effectively gateways to students' progress (Meyer \& Land, 2003). A study using threshold concept theory shed light on the importance of engineering students' understanding roles of engineers and the value of engineering (Male \& Bennett, 2015). This connection could be supported by more effective exposure to practice.

The research cited above, and other literature, indicates the value of participatory or situated learning that is consistent with experience in the workplace. This suggests that effective exposure to practice would be designed such that students participate in various types of engineering practice in interactive ways, using authentic tools and representations, while they develop positive identities as engineering students and subsequently as graduates and professionals. In the participatory framework, reflective practice is a way to build meaning from experiences and thereby construct understanding and identity. Reflective practice is necessary both to learn from experience and for lifelong learning and is recommended for work integrated learning (Orrell, 2011). The importance of reflective practice in helping engineering students to learn from workplace experiences has been recognised by Raelin (2007) and Kelly and Dansie (2012).

This framework provides a rationale for expecting that exposure to practice should help students to:

1. Develop more comprehensive and accurate understanding of engineering practice as socio-technical, thereby reducing surprises upon graduation;

2. Develop a sense of belonging to the faculty and the profession;

3. Develop motivation for learning due to recognition of relevance of the engineering program; and

4. Improve learning through understanding context and connections.

Our model of effective engineering education (Figure 1) stresses the importance of reflection on authentic and participative learning tasks. The latter involve exposure to practice that is valued by faculty and students. 


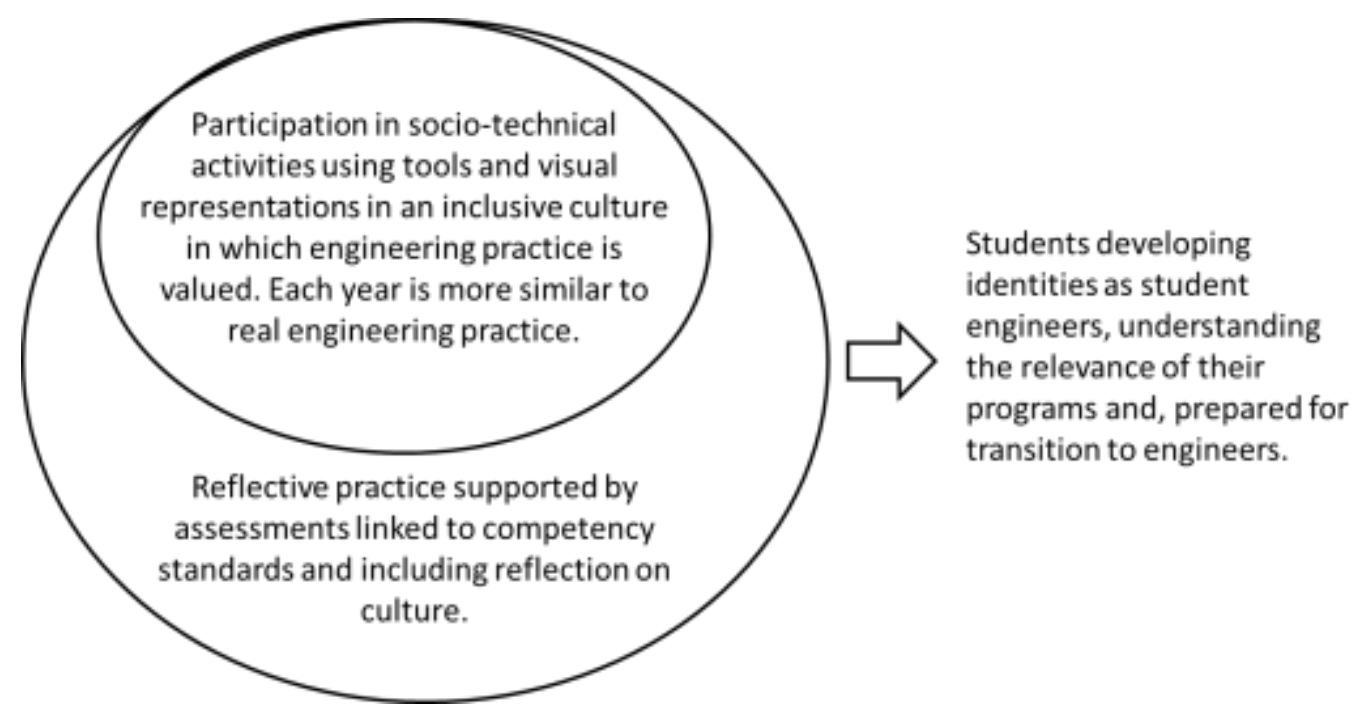

\section{Figure 1: Model of Effective Exposure to Engineering Practice in an Engineering Degree (Male \& King, 2014b)}

\section{The industry perspective}

We established industry members' perspectives on students' exposure to practice and with student engineers through employing students or collaborating with universities, through the steering committee and interviews with 38 selected practicing engineers and engineering professionals (Male et al., 2016). The principal benefits and difficulties identified are summarised in Table 2.

\section{Table 2: Engineering Employers Views on Engaging with Engineering Education}

\begin{tabular}{l|l}
$\begin{array}{l}\text { Employers' views on the benefits of } \\
\text { engaging with engineering education }\end{array}$ & $\begin{array}{l}\text { Employers' views on difficulties of engaging } \\
\text { with engineering education }\end{array}$ \\
\hline $\begin{array}{l}\text { Enhancing the organisation's brand among future } \\
\text { engineers }\end{array}$ & $\begin{array}{l}\text { Difficulties in engaging with the university } \\
\text { Perceptions that university people are out of } \\
\text { Improving students' understanding of working for } \\
\text { the organisation }\end{array}$ \\
$\begin{array}{l}\text { Prospective recruitment and opportunities to industry and worlds of work } \\
\text { Time and inconvenience involved in supervising } \\
\text { influence the capabilities of future graduates } \\
\text { Opportunities for professional development for } \\
\text { staff }\end{array}$ & $\begin{array}{l}\text { Industry experience is undervalued in teaching } \\
\text { Appeal to the organisation's employees and } \\
\text { personal satisfaction from teaching } \\
\text { Social license for the organisation }\end{array}$ \\
\hline
\end{tabular}

\section{Students' experience of practice: Focus groups}

Three student focus groups were held during 2013 to investigate engineering students' experiences of exposure to practice. We report the characteristics of the groups and the key points raised, using illustrative verbatim quotations.

Focus Groups $1(N=6)$ and $3(N=18)$ were at universities (one Group of Eight, one Australian Technology Network) that required their engineering students to complete 12 weeks of relevant experience, often as vacation employment. These universities had careers services, but students were generally expected to find their own employment. Focus Group 2 ( $N$ 
= 6) was at a university with a program in which students took 6 or 12 month internships for credit towards their degree. The university supported students to secure the internships. All students were in their final year except for four students in Group 3, two of whom had graduated and two of whom were expecting to complete their degrees in 2015. All but one was less than 26 years of age. Women were represented in all groups; there were no international students in Group 2.

The focus group sessions were semi-structured and of 50-70 minutes in duration. All students were asked to identify valuable exposure to engineering practice in their degrees, why it was valuable, what and how they had learned from it, how they changed from the experience, and how the experience could be improved. In Focus Group 2 the initial questions focused on the extended internships. No tight definition of exposure or value was made; the purpose was to discover the students' perceptions of these. The model in Figure 1 informed the follow-up questions and analysis of the transcribed students' comments, in which themes consistent with preparation for the transition to the workplace were identified.

Students reported diverse learning, particularly of non-technical matters, from their workplace experiences. This included understanding that employers do not expect graduates to know everything and that there is more to learn than they imagined. Learning professional communications requirements and reporting standards of a professional environment (contrasted with that of the student environment) featured strongly. Time management, business dynamics and the value of thinking about money and safety were referred to. Such experiences were reported as 'confidence building'. Motivation was identified by a student in Focus Group 1 in these terms:

The way in which the university is taught is quite... separated from what you might physically do in an industry environment. So the experience l've got outside put in perspective what I learned in class... Having outside experience gives you the motivation to go back into your engineering degree and finish it and come out.

In contrast, several students reported that their workplace experiences were boring, thereby risking the company reputation, while others in Focus Groups 1 and 3 regretted the limited diversity gained from a single experience, considering the many types of engineering roles and employers. In the words of a student in Focus Group 3:

In health faculties they have their pracs...they get a diverse range of opportunities, like geriatrics and paediatrics. Whereas in engineering if we do work experience in mining, invariably it's harder for us to then get into oil and gas as a graduate... It would be good if there was more opportunity for exposure to the different types of industry earlier on in our degrees.

Students appreciated the support that was available from the university's internship office to assist them in securing an internship. Others reported that it is difficult to secure vacation employment, especially for international students. Students indicated that the university-wide support such as careers fairs was not as helpful as events organised by engineering student societies. Students in Focus Group 3 reported that their university offered an alternative to 12 weeks of engineering employment, but they perceived this to be a poor substitute. In the words of two students:

You can make it up with ...things like going to technical presentations or workshop seminars... so you can... make up your required 12 weeks through no vacation work.

But... companies, are going to choose a person that's done [vacation] work.

Non-placement exposure to practice can also be authentic and effective. Examples of incurriculum exposure to practice included case studies, site visits and student projects. For example, one student declared:

The sustainability unit.... taught us how to work in a team. It was about safely moving hazardous waste from different ends of uni, and we wore the actual full gear. The 
second part of the unit was about negotiation ... One of us was the [government department] and another group was a company.

The experience of a site visit to a substation on campus was transformative in the sense that this student now took the point of view of an engineer,

This substation is... here; you don't... think that this is related to you until you get inside... and suddenly you feel like this is what l'm studying.

Students reported projects as providing valuable exposure to engineering practice, sometimes as part of a course, sometimes in extra-curricular voluntary contexts, and sometimes both. The first example below was undertaken as a project for a unit and also in a club. The second is an extra-curricular student competition. Both are socio-technical.

What made me want to become an engineer the most was the [recreational disability engineering company] project.... working on a project with a team and delivering... The clients... are the loveliest people in the world and quite severely disabled people and it's really rewarding... making people want to do engineering and... teaching people what an engineer does.

I've been doing motorsport.... The... team participates in ... an engineering design and build competition... A lot of what that has taught me... is a confidence... We have to discuss what we want with people that operate the machines, the business owners themselves.

Students in Focus Group 3 identified valuable exposure to practice from international summer exchanges and international workshops, site visits in units, a design unit in which students worked in groups on industry-based projects, and industry-based assignments and examples used by a lecturer with 15 to 20 years' experience in industry. Benefits of going to site are described below by two students:

With site visits... you really see what's happening. You can visualise things... When... you write procedures, at least you know what the procedures are about.

Like in the textbook a valve is this big [indicating small] and on a [drawing] it's that big, but in real life [indicating enormous]... Until a few months ago - and I heard of them for the last four years - I couldn't actually put it in perspective.

Students identified a unit for elite students taught entirely by a company over seven weeks, mostly on site. They appreciated procedural stuff and then seeing the actual units and what it looks like, what it sounds like, what it smells like. These students enjoyed spending the whole day on site, seeing the physical process plants, wearing safety gear everywhere, and meeting engineers at various levels.

A theme in Focus Groups 1 and 3 was the value of student societies. Students reported that networking events organised by engineering student societies helped them secure placements. Learning similar to that identified in the workplace was reported by students participating in extra-curricular activities organised through engineering student societies. Students felt that the student societies consistently invited high quality industry-based guests, as articulated by one student,

It's a reflection on our club and we all take great pride in our clubs... so we're not going to... have 100 students walk out of something they've voluntarily gone to and go 'Well that was a waste of time'.

In contrast, Focus Group 1 participants reported mixed experiences of guest lectures included in the formal curriculum:

[The poor speakers] are the worst because when they come in it just lowers your morale... 
Yeah quite depressing when you ... just walk out thinking I do not want to work there or I do not want to be that person.

But when you get a good teacher or someone who's very good at presenting it's very motivating.

\section{Students' experience of practice: Survey}

After a survey pilot in 2013, a student survey was conducted by email in March 2014, to quantify the exposure to engineering practice experienced by final-year engineering students from 11 universities. Valid responses were received from 215 students, 18.6 per cent of whom were female, and 27.0 per cent international, roughly representative of the national cohort. Mechanical engineering students were slightly over-represented in the student sample. Two of the universities operate with extended internships, contributing to over-representation of this group, compared with the national average.

The content questions were based on the types of industry engagement identified by EA (Table 1), with four items added based on findings from the focus groups. Students rated the incidence of their experience of each type of exposure to practice and how significantly this had increased their understanding of engineering practice. Table 3 provides these results, ordered by their rating of the learning significance of each type.

Table 3: Ratings of Experience of Exposure to Practice by Student Survey Participants (rank ordered by perceived value) $(N=215)$

\begin{tabular}{|l|c|c|c|}
\hline \multicolumn{1}{|c|}{ Type of industry engagement } & $\begin{array}{l}\text { \% who } \\
\text { experienced } \\
\text { engagement } \\
\text { at least } \\
\text { once of } \\
\text { responses } \\
\text { to relevant } \\
\text { question }\end{array}$ & $\begin{array}{l}\text { \% rating the } \\
\text { engagement } \\
\text { type as } \\
\text { significantly } \\
\text { increasing } \\
\text { their under- } \\
\text { standing of } \\
\text { engineering }\end{array}$ \\
\hline $\begin{array}{l}\text { employment experience } \\
\text {-engineering internships of } 6 \text { months or more } \\
\text {-12 weeks' vacation experience or equivalent part- } \\
\text { time work }\end{array}$ & 214 & 39.5 & 90.6 \\
\hline question & 211 & 49.8 & 88.8 \\
\hline industry-based final year projects & 213 & 64.2 & 53.6 \\
\hline guest lectures & 212 & 80.9 & 52.9 \\
\hline industry visits and inspections & 212 & 67.0 & 41.6 \\
\hline $\begin{array}{l}\text { hearing/reading about another student's workplace } \\
\text { experience }\end{array}$ & 214 & 80.5 & 39.3 \\
\hline $\begin{array}{l}\text { teaching by staff with recent, non-research industry } \\
\text { experience }\end{array}$ & 213 & 74.0 & 38.4 \\
\hline *series of meetings with an industry based mentor & 212 & 39.5 & 37.7 \\
\hline industry-based case studies & 214 & 67.0 & 36.9 \\
\hline *units run by one or more engineering employers & 212 & 45.6 & 35.7 \\
\hline $\begin{array}{l}\text { problem solving, projects, or evaluation tasks with } \\
\text { direct industry input of data and advice }\end{array}$ & 214 & 65.6 & 35.5 \\
\hline $\begin{array}{l}\text { *interaction with professional engineers through a } \\
\text { student society (e.g. motorsports, IEEE, Young } \\
\text { Engineers) }\end{array}$ & 212 & 47.9 & 34.0 \\
\hline
\end{tabular}




\begin{tabular}{|l|c|c|c|}
\hline $\begin{array}{l}\text { *laboratory sessions in emulated industrial } \\
\text { environments (e.g. manufacturing facilities, virtual } \\
\text { plants, miniature plants) }\end{array}$ & 212 & 49.3 & 28.4 \\
\hline interviewing of engineering professionals & 211 & 52.1 & 27.6 \\
\hline $\begin{array}{l}\text { studies of industry policies, processes, practices, } \\
\text { benchmarks }\end{array}$ & 213 & 62.8 & 24.4 \\
\hline
\end{tabular}

Notes. This analysis includes only the participants in the final year of a bachelor's degree or in an entry to practice masters. * The engagement types marked * were suggested by the student focus groups. Participants selected the number of times they had experienced each type of industry engagement $(0$, $1,2,3$ or more times). The figure in the third column is the percent who reported having experienced the type of industry engagement at least once of those who responded to the question. Of the 214 students who indicated whether they had completed 12 weeks of vacation engineering employment or equivalent part-time engineering work, or an internship, $62(29.0 \%)$ had neither vacation experience nor an internship.

Clearly, and not surprisingly, real employment experience rated very highly in adding significant understanding of engineering. Most respondents had experience of at least a short placement. However, 62 respondents (29\% of the sample) declared that they had not completed either an internship or placement before entering their final year of study. This quantifies the degree of frustration with not being able to gain mandated experience prior to completion of the academic program, as expressed by students in Focus Group 3.

The survey data show that students rated the types of engagement largely by their degree of 'authenticity'. Overall, the less authentic or less explicitly industry-focussed activities were perceived, on average, to add relatively little to understanding of practice.

The students' experience of self-reflection was surveyed in an additional question, with $73.4 \%$ of 213 respondents rating agreement below ' 4 ' on the five-point scale ( 1 = strongly disagree; 5 = strongly agree), with the statement that 'they had tracked their development towards engineering capabilities'. This finding is discussed below.

\section{Non-placement exposure to practice: Trialled initiatives}

The funded project also explored non-placement exposure to practice, by providing funding to support seven universities to develop, implement, and evaluate industry-inspired initiatives, mostly for large enrolment units in core curriculum areas. Their content involved about 30 engineering employers, and the initiatives were experienced by a total of 1,000 students during 2013-14.

The trialled initiatives were developed in a relatively short time. The funding allowed for approximately one month of academic support to conceptualise each initiative and develop materials. The initiatives themselves had to fit into the structure and goals of an existing unit, without needing major academic approval; effectively they were industry-explicit interventions in otherwise 'academically-focussed' curricula.

Different types of interventions were trialled. In core engineering units, such as mechanics, dynamics and electrical energy systems, students were provided with real data from the field, and industry standard software from which they were required to devise and test simulated solutions, and compare with implemented solutions. An intervention in the area of engineering project management allowed students to work on parts of a major project design in their city. Another had students interviewing practicing engineers to assist them to understand issues in their project work. In a unit on risk management for 200 students, academics developed, in collaboration with the company, a flipped-classroom case study on incident analysis, based on a real industrial accident. This required the engineering students to deal formally with safety protocols and individuals' actual incident reports, socio-technical dimensions rarely covered in engineering programs, but vital in practice. 
Evaluations of these interventions at each institution, and by an independent evaluator, indicated positive impacts on students' learning, attributed largely to the industrial authenticity of the activities and the personnel involved with their development and delivery. The benefits included deepening of fundamental concepts, the use of industry-standard simulation tools and 'real' data, and improved self-reflection. Students were also challenged by the uncertainties in tackling genuine open-ended problems. The materials produced for each initiative have been packaged for others to use.

\section{Discussion}

The focus group findings and survey results indicated that students learn much from industry placements and other workplace-based activities, including motivation, confidence, recognition of the relevance of their programs, and professional competency development. Indeed, placements were perceived by many students to be the only effective exposure to practice in a program perceived as otherwise irrelevant to practice.

The study also confirmed that many (approximately 30\% in some institutions) students found it difficult or impossible to secure industry placements, while most classroom-situated learning methodologies individually are neither sufficiently reliable nor sufficient in quality and depth to deliver strong exposure to practice. Students from one university who were allowed to accumulate exposure to practice through non-placement means perceived this approach to be less beneficial to their career development than a placement. Even those who secured placements recognised the limitation of working in one organisation only. Furthermore, very few students tracked their personal development of engineering capabilities throughout their programs. Although writing a diary of placement activities was routine, requiring reflective tracking was very uncommon in 2013.

Although workplace learning is clearly valuable and valued, it is not feasible to find or provide good quality 12 week industry placements to all engineering students. The study findings indicate that a well-designed combination of in-curriculum and extra-curricular activities can deliver good exposure to practice. The trialled non-placement initiatives described above provide examples of within-curriculum methods (Male \& King, 2014b). The data also indicate where improvements can be made. For example, most students experienced the sixth rated item in the survey, 'hearing or reading about another student's workplace experience', informally. Given the wide range of placements experienced by a cohort of students, this activity could be usefully formalised and enhanced to encourage and deepen students' skills of reflection, while assisting them to understand the variety and breadth of engineering practice.

\section{Guidelines for effective industry engagement}

From these findings, guidelines (Male \& King, 2014a) were developed to assist the three key stakeholder groups - the faculties, industry, and government/professional bodies to achieve stronger and more reliable graduate outcomes.

The underlying educational model as expressed in Figure 1, and in the preamble to the Guidelines, is elaborated in two themes: (1) curriculum design and delivery incorporate the spectrum of local and global engineering practice, and (2) engineering education incorporates the students' whole experience.

Each of these themes is further elaborated in terms of the engagement of academics and students in the design and delivery of the curriculum. We emphasise the active participation of the students in their development from 'student engineers' to becoming competent, motivated, professional graduates and assert the development of their identities and self-efficacy through gaining confidence in the development of their knowledge and skills. This in turn requires an understanding of and confidence in achieving possible future roles, that exposure to practice can convey. 
The guidelines take the form of recommendations, as in Table 2. Their emphasis is directed towards the faculties, because they are ultimately responsible for leading and implementing improved educational practices (Table 4). ACED has adopted them as a basis for improvement. Each recommendation has an explanatory paragraph, and examples and links to current examples of effective practice. In total, 36 models and examples of effective practice are referenced.

\section{Table 4: Summary of Guideline Recommendations (Male \& King, 2014a)}

\section{Recommendations to Faculties}

An engaged faculty will:

F1 Establish and maintain effective industry engagement as part of faculty culture, with

(a) people, processes, and resources to ensure strong relationships with industry;

(b) structural and developmental support for academics to engage with industry;

(c) employment of engineers with industry experience to facilitate students' learning;

(d) structured and transparent industry consultation.

F2 Use industry-based assignments in engineering degree programs.

F3 Provide student engineers with substantial opportunities to work and learn in industry.

F4 Provide most students with opportunities to undertake industry-based final year (capstone) projects.

F5 Develop emulated work-integrated learning, as an example of effective industry engagement.

F6 Encourage students to take responsibility for seeking opportunities in engineering practice.

F7 Support and recognise industry engagement undertaken by student groups.

\section{Recommendations for Industry}

Establishing and maintaining principles of mutual benefit is paramount. Employing organisations should:

I1 Provide regular and structured student engineer employment.

12 Provide support for their engineers to engage with engineering education.

I3 Provide support for academics to experience industry.

Recommendations for Professional and Industry Peak Bodies, and Governments

Recognising the facilitative role of such bodies:

B1 Professional and industry peak bodies, universities, student societies, and the Australasian Association for Engineering Education, should consider jointly establishing a resource centre to support students' industry engagement.

B2 Governments, professional and industry peak bodies, and engineering faculties should consider establishing joint national or state based internship schemes.

B3 Engineers Australia should consider developing an e-portfolio resource for student engineers.

B4 Industry peak bodies should foster a culture of industry engagement with education.

B5 Government should consider incentives for employers to support industry engagement in engineering education.

B6 Engineers Australia's program accreditation criteria and guidelines on exposure to engineering practice should be reviewed to reflect changing employment conditions and other factors.

\section{Recent changes and new approaches}

In the four years since these baseline data were collected there has been increasing national attention on employability, and the quality and quantity of work integrated learning. In 2015 the higher education and business peak bodies announced a National WIL Strategy (Universities Australia et al., 2015) for all undergraduate degrees. The quality assurance agency has subsequently produced a Guidance Note (Australian Government Tertiary Education Quality and Standards Agency, 2017) that incorporated experience from the ACED community, but also challenges the 'unsupervised' model of industry placement that has been typical of engineering for many decades. 
The ACED community, through its network of associate deans of learning and teaching, has worked with officers of the EA Accreditation Centre to update its accreditation criterion and guidance on exposure to practice, renamed as 'engagement with professional practice'. The change of focus from 'exposure' to 'engagement' is indicative of the importance that the engineering education and professional community sees for this dimension of the engineering qualification. The changes are outlined below. In addition, several faculties have made the traditional form of industry placement optional, and have improved the quality and quantity of non-placement engagement with practice, to ensure compliance with the accreditation requirements, and improve the quality of the curriculum. Examples are outlined.

\section{EA accreditation changes: Engagement with professional practice}

In support of the engineering education model depicted in Figure 1, the revised EA accreditation criterion and guideline (Engineers Australia Accreditation Centre, 2019) emphasises that the purpose of EPP is to initiate the development of sound engineering judgement and decision-making that conform to EA's Code of ethics, and to embed good work practices and methods that the student will carry beyond their degree program. The revised guideline emphasised that students should learn (experientially) about systems for engineering work management, professional engineering communications, professional behaviour with workmates and clients, the constraints of commerce, and ideally, the disturbances that occur in the professional environment. All of these are very different from the education environment.

EA continues to recommend that students have opportunities to undertake formal work placements, and has developed a supporting website and other means to assist students to locate suitable employers. The revised accreditation guideline recommends, however, that 'formal work placements' (where implemented) are documented with appropriate intended learning outcomes.

Most importantly, the revised accreditation guideline expects that graduate capabilities related to professional practice are developed throughout the whole degree program. To support that end, the guideline includes an updated and refined list of activities and methodologies, listed in Table 5, to replace those in Table 1. Through adoption of a good balance of these, ALL students will have a stronger engagement with professional practice.

Furthermore, EA specifies that the faculty should adopt systems, such as e-portfolios, for students to record and track their development of their capabilities.

Table 5: Engineers Australia's Revised List of Methodologies and Activities for Students' Engagement with Professional Practice (Engineers Australia Accreditation Centre, 2019)

\begin{tabular}{l}
$\begin{array}{l}\text { Systematic contact with practicing professionals, for example, through on-going project } \\
\text { reviews, mentoring, or professional society activities }\end{array}$ \\
\hline Engineering information management, especially management of an engineering baseline \\
\hline Direct industry input to authentic problem-solving, projects and evaluation tasks \\
\hline Industry-based investigations and case studies, including final year projects \\
\hline Industrial site visits that contribute to learning outcomes \\
\hline Inclusion of staff with industry experience in curriculum delivery \\
\hline Guest lectures by industry practitioners \\
\hline Application of industry standards, codes, practices and methods \\
\hline Structured interviews of engineering professionals \\
\hline
\end{tabular}




\section{New approaches to in-curriculum engagement with practice}

A team is developing and trialling non-placement learning modules in which engineering students engage with workplaces, authentic processes, and/or practitioners using electronic means (Male, Hargreaves, \& Pointing, 2017). Learning activities include:

- electronic interviews of and with engineers;

- communications and self-management exercises in authentic engineering scenarios in simulated workplaces and reflection on them electronically with engineers;

- authentic safety in design, tendering, or maintenance exercises using a virtual site or virtual reality.

Elements of the modules have been tested with up to 25 students. A module in which students use an authentic meeting-based process for identifying, analysing and remediating hazards was successfully used with 280 students in two capstone design units (Male et al., 2018).

Many universities have established preparation for placements (Jollands, Boles, \& Peterson, 2017), introduced optional credit-bearing placement units, structured non-credit-bearing work integrated learning in all years of the curriculum (Kadi \& Lowe, 2018), and embedded nonplacement work integrated learning across the curriculum. Some universities are using agencies to assist students with finding placements and are providing pre-placement training.

\section{Conclusion}

The workplace-based means by which engineering students have traditionally been exposed to engineering practice have been increasingly difficult to sustain and deliver due principally to changes in the engineering industry sector and the increasing numbers of engineering students. Providing in-curriculum exposure to engineering practice has also been challenged by employing fewer engineering academics with engineering experience outside research.

The collaborative study reported here was completed four years ago. It provided evidence of the views of industry and graduating year students on their exposure to practice. Industry values having access to students and universities, though may find engagement difficult. Students rated the activities and methodologies which aim to convey understanding of engineering practice, roughly in proportion to their authenticity. They rated extended industry placements most highly, but often sought more diversity of experience than one placement can provide.

The study revealed that there were many effective, but underutilised, in-curriculum approaches that could be used to improve the exposure of all students to practice throughout their engineering programs. Working with industry members, educators could extend practice to the classroom through projects, simulations, case studies, and electronic connection to practicing engineers, bringing people with experience into units in meaningful ways. Extracurricular engineering activities, such as those run by student societies, could be better supported. Students should also be supported to reflect on and track their learning throughout their programs.

Taking the theoretically-based perspective that stronger engineering capabilities would be developed by embedding them throughout the curriculum, while the students develop their self-identity and self-efficacy with their chosen field, the study developed guidelines for good practice and recommendations for the engineering faculties, industry partners and external bodies, for improving engagement with practice.

Many of these recommendations and improvements are now being adopted, often collaboratively. The external accreditation body, Engineers Australia has revised its criterion and guideline on engagement with professional practice. This will assist providers to improve their delivery of quality engineering education and of graduates who have the capabilities required by contemporary employers. Australian universities, in turn, are revising their 
approaches to engineering practice in their own program revisions and new engineering degree proposal.

\section{Acknowledgements}

This work was supported by Australian Government Department of Industry, Workplace Innovation Program by a grant awarded to the Australian Council of Engineering Deans. The authors gratefully acknowledge the volunteer participants; the project work and other contributions by representatives of the partner universities: Australian Maritime College (University of Tasmania), Curtin University, Deakin University, James Cook University, Swinburne University of Technology, RMIT University, The University of Melbourne, The University of Western Australia, Queensland University of Technology, University of South Australia, University of Southern Queensland, The University of Sydney, University of Technology Sydney; and members of the Reference Group: Tara Diamond, Australian Mines and Metals Association; Peter Hoffmann, Engineers Australia Accreditation Centre; Lindsay Le Compte, Australian Constructors Association; Gavin Lind, Minerals Tertiary Education Council; Stuart Payne, WorleyParsons; Jonathan Russell, Consult Australia; Roma Sharp, The Australian Petroleum Production \& Exploration Association; and Alex Sparvell, Engineers Australia. 


\section{References}

Australian Council of Engineering Deans. (2017). Australian Engineering Education Student and Staff Statistics from National Data Collections - Januay 2017. Retrieved from https://www.engineersaustralia.org.au/sites/default/files/resource-files/201704/ACED\%20Engineering\%20Stats\%2031\%20Jan\%202017.pdf

Australian Government Department of Education \& Training (2018). Selected Higher Education Statistics - 2017 Student data. Retrieved from https://www.education.gov.au/selectedhigher-education-statistics-2017-student-data

Australian Government Tertiary Education Quality and Standards Agency. (2017). Guidance Note: Work Integrated Learning. Retrieved from https://www.teqsa.gov.au/latestnews/publications/guidance-note-work-integrated-learning

Billett, S. (2011). Final report curriculum and pedagogic bases for effectively integrating practicebased experiences. Retrieved from Strawberry Hills NSW: http://www.altcexchange.edu.au/group/integrating-practiceexperiences-within-highereducation

Blandin, B. (2012). The Competence of an engineer and how it is built through an apprenticeship program: A tentative model. International Journal of Engineering Education, 28(1), 57-71.

Bodmer, C., Leu, A., Mira, L., \& Rutter, H. (2002). SPINE: Successful Practices in International Engineering Education. Retrieved from http://www.ingch.ch/pdfs/spinereport.pdf

Bradley, A. (2008). Accreditation Criteria Guidelines Document G02 Rev 2 (G02). Retrieved from Barton, ACT: https://www.engineersaustralia.org.au/sites/default/files/content-files/201612/G02_Accreditation_Criteria_Guidelines.pdf

Cameron, I., Reidsema, C., \& Hadgraft, R. (2011, 5-7 December). Australian engineering academe: a snapshot of demographics and attitudes. Paper presented at the 22nd Annual Conference of the Australasian Association for Engineering Education, Fremantle, WA.

Engineers Australia. (2013). Australian Engineering Stage 1 Competency Standards for Professional Engineers. Retrieved from Barton ACT: https://www.engineersaustralia.org.au/sites/default/files/content-files/201612/doc21_p05pe_ea_stage_1_competency_standards_for_pe.pdf

Engineers Australia Accreditation Centre. (2019). Accreditation Criteria User Guide - Higher Education AMS-MAN-10, section 3.4.

Faulkner, W. (2007). "Nuts and bolts and people": Gender-troubled engineering identities. Social Studies of Science, 37(3), 331-356.

Godfrey, J. E., \& King, R. (2011). Curriculum specification and support for engineering education: understanding attrition, academic support, revised competencies, pathways and access. Strawberry Hills NSW: Australian Learning \& Teaching Council.

International Engineering Alliance. (2014). 25 Years Washington Accord. Retrieved from http://www.ieagreements.org/25_years/25YearsWashingtonAccord-A5booklet-FINAL.pdf

Jollands, M., Boles, W., \& Peterson, J. F. (2017). Developing students' employability in work placements. Paper presented at the Australasian Association for Engineering Education Conference, Manly, Sydney, Australia.

Kadi, A., \& Lowe, D. (2018, 9-12 December 2018). A new professional engagement program outline and initial outcomes. Paper presented at the Australasian Association for Engineering Education Conference, Hamilton, New Zealand.

Kelly, P., \& Dansie, B. (2012). S 2 P student to practice, Hubs and Spokes Project Report.

King, R. (2008). Addressing the Supply and Quality of Engineering Graduates for the New Century. Retrieved from Surrey Hills NSW:

Leydens, J. A. (2012). Sociotechnical communication in engineering: an exploration and unveiling of common myths. Engineering Studies, 4(1), 1-9. doi:10.1080/19378629.2012.662851

Male, S. A., \& Bennett, D. (2015). Threshold concepts in undergraduate engineering: Exploring engineering roles and value of learning. Australasian Journal of Engineering Education, 20(1), 59-69.

Male, S. A., Bush, M. B., \& Chapman, E. S. (2010). Perceptions of competency deficiencies in engineering graduates. Australasian Journal of Engineering Education, 16(1), 55-68. 
Male, S. A., Hargreaves, D. J., \& Pointing, D. (2017, 10-13 December). The emerging suite of virtual work integrated learning modules for engineering students. Paper presented the 28th Annual Conference of the Australasian Association for Engineering Education (AAEE 2017), Manly, NSW.

Male, S. A., Kenworthy, P., Hassan, G. M., Guzzomi, A. L., Van der Veen, T., \& French, T. (2018). Teaching safety in design in large classes using VR. Paper presented at the Australasian Association for Engineering Education Conference, Hamilton, New Zealand.

Male, S. A., \& King, R. (2014a). Best Practice Guidelines for Effective Industry Engagement in Australian Engineering Degrees. Retrieved from http://www.aced.edu.au/ doi:10.13140/RG.2.2.31950.87364

Male, S. A., \& King, R. (2014b). Improving industry engagement in engineering degrees. Paper presented at the 25th Australasian Association for Engineering Education Conference, Wellington, New Zealand.

Male, S. A., King, R., \& Hargreaves, D. (2016). Drivers and barriers to industry engaging in engineering education. Paper presented at the 12th International CDIO Conference, Turku University of Applied Sciences, Turku, Finland. http://julkaisut.turkuamk.fi/isbn9789522166104.pdf

Meyer, J. H. F., \& Land, R. (2003). Enhancing Teaching-Learning Environments in Undergraduate Courses Occasional Report 4. Retrieved from http://www.etl.tla.ed.ac.uk/docs/ETLreport4.pdf

Nair, C. S., Patil, A., \& Mertova, P. (2009). Re-engineering graduate skills - a case study. European Journal of Engineering Education, 34(2), 131-139.

Orrell, J. (2011). Good practice report: work integrated learning. Retrieved from Surry Hills, NSW: http://www.olt.gov.au/resource-work-integrated-learning-2011

Palmer, S., Tolson, M., Young, K., \& Campbell, M. (2015). The relationship between engineering bachelor qualifications and occupational status in Australia. Australasian Journal of Engineering Education, 20(2), 103-112. doi:10.1080/22054952.2015.1092666

Prinsley, R., \& Baranyai, K. (2015). STEM skills in the workplace. Occasional Paper Series Issue 9, (9). Retrieved from http://www.chiefscientist.gov.au/wpcontent/uploads/OPS09_02Mar2015_Web.pdf

Raelin, J. A. (2007). Toward an epistemology of practice. Academy of Management Knowledge \& Education, 6(4), 495-519.

Rooney, D., Boud, D., Reich, A., Fitzgerald, T., Willey, K., \& Gardner, A. (2012, 2-5 December). Using practice theory to investigate professional engineers' workplace learning. Paper presented at the 23rd Annual Conference of the Australasian Association for Engineering Education Conference, Swinburne University of Technology, Melbourne.

Sheppard, S. D., Macatangay, K., Colby, A., \& Sullivan, W. M. (2009). Educating engineers: Designing for the future of the field. San Francisco, CA: Jossey-Bass.

Spinks, N., Silburn, N., \& Birchall, D. (2006, March). Educating engineers for the 21st century: The industry view. Retrieved from http://www.raeng.org.uk/news/releases/henley/pdf/henley_report.pdf

Tilli, S., \& Trevelyan, J. P. (2010). Labour Force Outcomes for Engineering Graduates in Australia. Australasian Journal of Engineering Education, 16(2), 101-122.

Trevelyan, J. P. (2010). Reconstructing Engineering from Practice. Engineering Studies, 2(3), 21. Universities Australia, Australian Chamber of Commerce and Industry, Ai Group, Business Council of Australia, \& Australian Collaborative Education Network. (2015). National Strategy on Work Integrated Learning in University Education. Retrieved from http://cdn1.acen.edu.au/wp-content/uploads/2015/03/National-WIL-Strategy-in-universityeducation-032015.pdf 